\title{
EFFECTS OF WATER POLLUTION ON ASSEMBLAGES OF AQUATIC FUNGI
}

\author{
M.A.S. Graça \\ Departamento de Zoologia, Universidade de Coimbra, 3049 Coimbra Codex, Portugal.
}

Key words: Aquatic fungi, water pollution, Streams.

\begin{abstract}
The assemblages of aquatic fungi in a river receiving strong mine and sewage pollution was analyzed. The structure of fungal assemblages was similar in all sampling sites suggesting that aquatic hyphomycetes are not reliable indicators of water quality.
\end{abstract}

\section{INTRODUCTION}

Many river systems depend upon allochthonous organic matter as source of energy and nutrients (KAUSHIK \& HYNES, 1971; ANDERSON \& SEDELL, 1979). Such material consists mainly of structural compounds, rich in energy but difficult for animals to break down. Fungi, particularly the aquatic hyphomycetes are able to exploit this energy by means of extracellular enzymatic digestion.

Stream detritivores select and survive better on substrates that have been previously colonized by fungi (KOSTALOS \& SEYMOUR, 1976; ROSSI \& FANO, 1979; BUELER, 1984). This has been interpreted as a way by which detritivores can overcome the lack of an efficient enzymatic system capable of digestion structural plant compounds.

Having a key role in the energy recovery from the leaf litter, it is reasonable to expect that interferences in the normal functioning in the assemblages of aquatic fungi, will be reflected on animal populations depending on it.

Here I examine the effects of pollution (organic and mine effluent) on assemblages of aquatic fungi at the Wallen stream (R. Trent system, central England).

\section{MATERIAL \& METHODS}

In November 1987, two leaf packs ( $3 \mathbf{g}$ ) of sycamore and two leaf packs ( $3 \mathrm{~g}$ ) of alder were placed at 4 sites in the stream, attached to submerged stones exposed to the current. Two we- eks later, two leaves were taken from each pack, washed with sterile distilled water and 10 leaf discs cut from each leaf using a cork borer. The cork borer was sterilized after each operation by submersing it in $80 \%$ ethanol and passing it through a flame. A total of 80 leaf discs were obtained for each site.

Leaf discs were individually incubated in sterile artificial pond water (APW - Ca, $80 \mathrm{mg} \mathrm{l}^{-1} ; \mathbf{C l}, 145 \mathrm{mg} \mathrm{l}^{-1} ; \mathrm{Mg}, 12 \mathrm{mg} \mathrm{l}^{-1}$; $\mathrm{Na}, 18 \mathrm{mg} \mathrm{l}^{-1} ; \mathrm{K}, 3 \mathrm{mg} \mathrm{l}^{-1}$ ) at a temperature similar to the river water $\left(15^{\circ} \mathrm{C}\right)$. Two to five days later, discs and conidia were stained with lactophenol blue, observed under the microscope and conidia identified. The relative importance of species (in terms of abundance and distribution) was determinated using the RIV method described by SHEARER \& WEBSTER (1985a, b). As a modification of the original method, RIV was divided by 2 in order to deal with a scale varying between 0 (an infinite number of species equally distributed in all leaf discs) and 100 (only one species present in all leaf discs).

At montly intervals and for a period of one year severalenvironmental parameters were measured in the river water in the referred 4 sites $(1,2,4,5)$, and in an intermediated site (3). The oxygen content in the water was measured, using a Harris Environmental Test Center oxygen-meter, and four $250 \mathrm{ml}$ water samples were collected for other chemical determinations in the laboratory: conductivity with a Y.S.I. Model 33 S-C-T conductivity/salinity meter, $\mathrm{pH}$ with a Coming $\mathrm{pH}$ meter 109, alkalinity, by titration of $50 \mathrm{ml}$ of the sample against $0.001 \mathrm{~N}$ hydrochloric acid until $\mathrm{pH} 4.5$, recorded by a $\mathrm{pH}$ meter (MACKERETH MERON \& TALLING, 1978); calcium, using 
an ion specific electrode (Orion calcium electrode model 93-29) and the anions fluoride, bromide, chloride, nitrates, phosphates and sulphates, in a Dionex 2000 analyzer. Two of the $250 \mathrm{ml}$ samples (BOD bottles) were incubated in the dark at $20^{\circ} \mathrm{C}$ and the oxygen content measured after five days to determine the $\mathrm{BOD}_{5}$ (MACKERETH et al., 1978).

\section{RESULTS}

Water chemistry at Sites 1 to 4 was very similar (Table 1). At Site 5 there was a reduction in the dissolved oxygen content of the water and an elevation in the $\mathrm{BOD}_{5}$, temperature, calcium, chloride, fluoride, bromine, sulphate and conductivity values. These changes in the water chemistry were related to the input of effluent from a coal mine and sewage treatment works between Sites 4 and 5 .

TABLE 1. Mean values for some physico-chemical variables at 5 sampling sites of Wallen stream (April 1987 to March 1988) and statistical comparisons between sites (ANOVA) (temp. = temperature in "C., $\mathrm{mi}=$ minimum, ma = maximum; variables other than $\mathrm{pH}$ in $\mathrm{mg} \mathrm{l-')}$.

\begin{tabular}{|c|c|c|c|c|c|c|}
\hline \multirow[b]{2}{*}{ Variables } & \multicolumn{6}{|l|}{ Sites } \\
\hline & & 2 & 3 & 4 & 5 & $F(d . f)) P$ \\
\hline Temp.(mi) & 6.4 & 7.4 & 6.3 & 7.3 & 10.5 & $2.51(4,38)$ n.s. \\
\hline Temp.(ma) & 14.6 & 11.5 & 13.9 & 11.9 & 13.9 & $2.06(4,38)$ n.s. \\
\hline $\mathrm{O}_{2}$ & 12.0 & 11.8 & 11.6 & 11.7 & 8.8 & $3.59(4,52){ }^{*}$ \\
\hline $\mathrm{BOD}_{5}$ & 1.6 & 1.6 & 4.1 & 3.8 & 24.2 & $13.72(4.42)^{\star \star *}$ \\
\hline $\mathrm{pH}$ & 7.8 & 7.4 & 7.6 & 7.5 & 7.5 & $3.80(4.52))^{\star *}$ \\
\hline $\mathrm{Ca}^{++}$ & 90 & 85 & 89 & 127 & 162 & $5.69(4.52){ }^{\star \star \star}$ \\
\hline Alkalinity & 4.8 & 5.8 & 4.8 & 5.2 & 5.6 & $0.83(4.52) n_{i} s_{\dot{*}}$ \\
\hline Conductiv. & 0.1 & 0.1 & 0.1 & 0.2 & 0.4 & $19.16(4.52)^{\star \star \star}$ \\
\hline $\mathrm{F}^{-}$ & 0.1 & 0.1 & 0.2 & 0.1 & 1.0 & $1.93(4.25)$ n.s. \\
\hline $\mathrm{B} \mathrm{r}$ & 0 & 0 & 0.5 & 2.0 & 15.5 & $30.85(4,29){ }_{\star \star \star}^{\star \star}$ \\
\hline $\mathrm{Cl}^{-}$ & 50 & 80 & 70 & 250 & 1400 & $5.20(4,29){ }^{\star \star}$ \\
\hline $\mathrm{NO}_{3}^{-}$ & 110 & 40 & 60 & 56 & 54 & $8.08(4,29)^{\star \star *}$ \\
\hline $\mathrm{HPO}_{4}^{-}$ & 0 & 0 & 4 & 1 & 2 & $10.80(4,29) * * *$ \\
\hline $\mathrm{SO}_{4}^{=}$ & 126 & 124 & 120 & 150 & 156 & $3.63(4,29)^{*}$ \\
\hline
\end{tabular}

n.s. $=\mathrm{P}>0.05 ; *, * *, * * *=\mathrm{P}<0.05,0.01,0.001$

Only 12 aquatic taxa were recorded in this survey. In Fig. 1 the species are plotted in order of decreasing importance (RIV value) for all sites. Tetracladium marchalianum was the most abundant species, followed by Lemonniera aquatica, Anguillospora longissima and Articulospora tetracladia. The other taxa present were Tetracladium setigerum, Fusarium cavispermum, Tricladium angulatum, Cylindrocarpon sp., Heliscus lugdunensis, Clavariopsis aquatica, Fusarium sp. and Varicosporum graminea. Sites in which the canopy covered the river bed ( 2 and 4 ) had a higher diversity, recorded as number of species. A lower diversity was recorded in Sites 1 and 5.

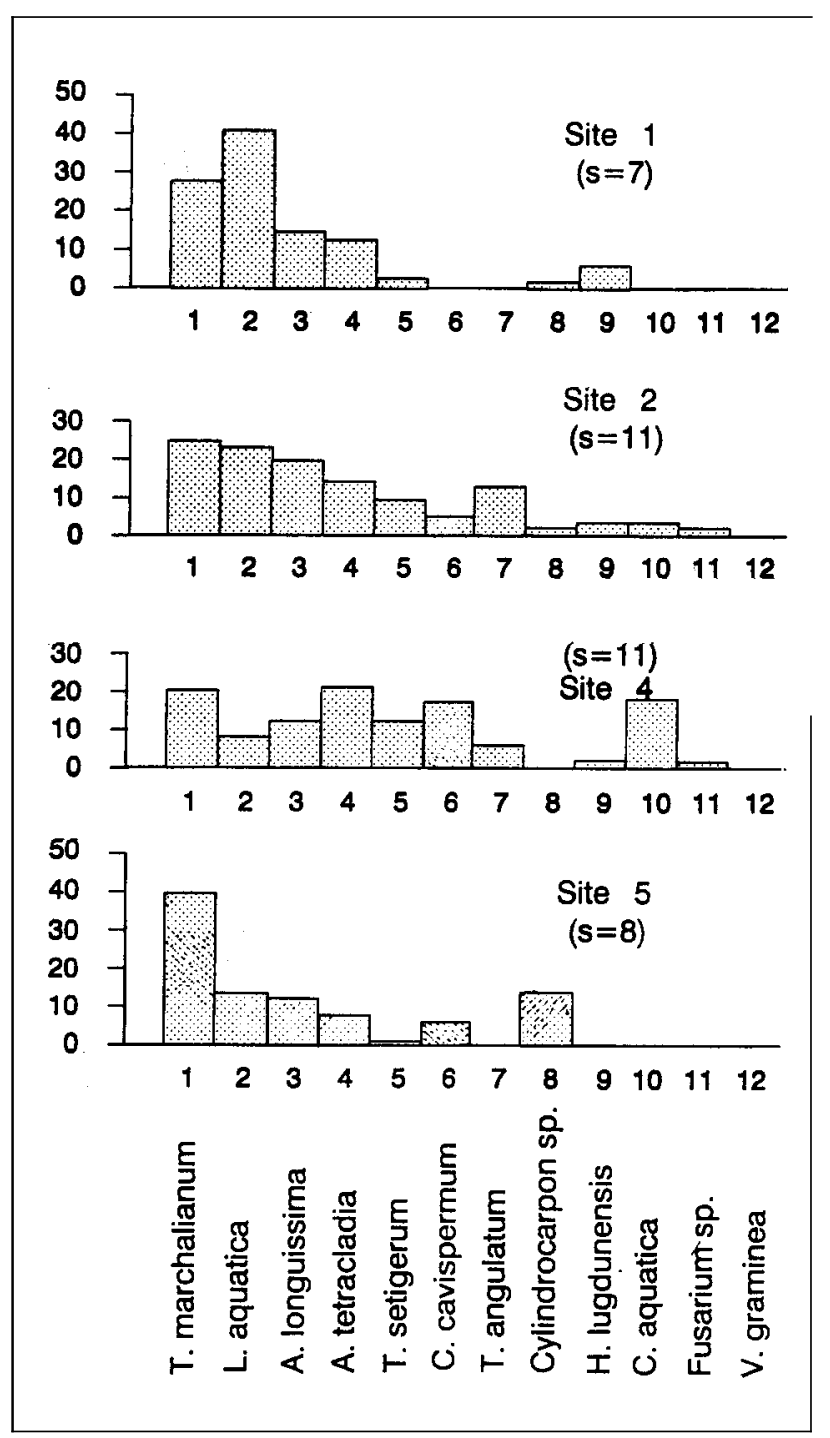

FIGURE 1. Relative abundance (RIV value) of 12 aquatic fungi in four sampling sites along the Wallen stream ( $\mathrm{s}=$ number of species).

\section{DISCUSSION}

The diversity of aquatic fungi observed in the Wallen stream was very low when compared with other surveys carried out elsewhere in Britain (e.g. IQBAL \& WEBSTER, 1973; SHEARER \& WEBSTER, 1985a). This may be attributed to the chemical composition of the water. In all sampling sites the $\mathrm{pH}$ values were always higher than 7.5 and calcium content and conductivity were also high. A negative correlation has frequently been observed between $\mathrm{Ca}^{++}$content of the water, high $\mathrm{pH}$ values and species richness (BARLOCHER \& ROSSET, 
1981; WOOD-EGGENSCHWILLER \& BÄRLOCHER, 1983; CZECZUGA \& PROBA, 1987). The type of species recovered from the Wallen stream agrees with what has been found in streams and rivers with similar water characteristics. E.g. L. aquatica and $\boldsymbol{T}$. marchalianum, the two most abundant species were referred to, by BARLOCHER \& ROSSET (1981), as the dominant species in nvers with pH 7.3 - 8.4 (the authors also added to this list C. aquatica, A. acuminata, C. longibranchiata, and H. lugdunensis).

The structure of the community of aquatic hyphomycetes was very similar between all sampling sites in terms of number of species and their abundance. Site 5 can be regarded as polluted, but according to the results obtained here, changes in the water quality did not have a great effect on the composition of the fungal community. The influence of pollution on aquatic hyphomycetes is not well established. CZECZUGA \& PROBA (1987) found a negative correlation between B.O.D. and species richness, but no significant differences between polluted and clean sites were observed by SUBERKROPP $\boldsymbol{e t}$. al. (1988).

According to the data here presented, aquatic fungi seems to be relatively tolerant to the pollution (the polluted site was only inhabited by oligochaetes, red chironomis and Asellus aquaticus L.). However, we do not know how pollution may affect rates of grow and nutrient cycling. We can also speculate that sites $1-4$ are already stresses due the natural water chemistry and therefore only tolerant species are present at these sites and site 5 .

Due their role in the energy transference of rivers it is fundamental to further investigate the effects of pollution on the structure and functioning of assemblages of aquatic fungi. In particular, we need to investigate if aquatic hyphomicetes do accumulate toxic compounds and how decomposition rates are effected by pollutants.

\section{AKNOWLEDGMENTS}

I would like to thank Professor J. Webster and L. Maranova for their valuable help on taxonomy and Dr. L. Maltby and Professor P. Calow for their encouragement. This research was supported by the Instituto Nacional de Investigação Científica (I.N.I.C.).

\section{REFERENCES}

ANDERSON N.H. \& J.R. SEDELL. 1979. Detritus processing by macroinvertebrates in stream ecosystems. Annual Review of Entomology. 24:351-357.
BÄRLOCHER F. \& J. ROSSET. 1981. Aquatic hyphomycetes spora of two Black Forest and two Swiss Jura streams. Transactions of the British Mycological Society. 76:479-483.

BUELER C.M. 1984. Feeding preference of Pteronarcys pictetii (Plecoptera: Insecta) from a small, acid, woodland stream. Florida Entomologist. 67:393-401.

CZECZUGA B. \& D. PROBA. 1987. Studies on aquatic fungi VII. Mycoflora of the upper part of the River Narew and its tributaries in a different environment. Nova Hedwigia. 44:151-161

GRAÇA M.A.S., Observations on the feeding biology of two stream-dwelling detritivores: Gammarus pulex and Asellus aquaticus.

IQBAL S.H. \& J. WEBSTER. 1973. Aquatic hyphomycete spora of the River Exe and its tributaries. Transactions of the British Mycological Society. 61:331-346.

KAUSHIK N.B. \& H.B.N. HYNES. 1971. The fate of dead leaves that fall into streams. Archiv fr Hydrobiologie. 68:14651515.

KOSTALOS M. \& R.L. SEYMOUR. 1976. Role of microbial enriched detritus in the nutrition of Gammarus minus (Amphipoda). Oikos. 27:512-516.

MACKERETH F.J.H., J. MERON \& J.F. TALLING. 1978. Water Analysis: Some Revised Methods for Limnologists. Freshwater Biological Association. Scientific Publication No 36, Kendal.

ROSSI L. \& E. A. FANO. 1979. Role of fungi in the trophic niche of the congeneric detritivores Asellus aquaticus and Proasellus coxalis (Isopoda). Oikos. 32:380-385.

SHEARER C.A. \& J. WEBSTER. 1985a. Aquatic hyphomycete communities in the River Teign. I. Longitudinal distribution patterns. Transactions of the British Mycological Society. 84:489-501.

SHEARER C.A. \& J. WEBSTER. 1985c. Aquatic hyphomycete communities in the River Teign. III. Comparison of sampling techniques. Transactions of the British Mycological Society. 84:509-518.

SINSABAUGH R.L., A.E. LINKINS \& E.F. BENFIELD. 1985. Cellulose digestion and assimilation by three leaf-shredding aquatic insects. Ecology. 66:1464-1471.

SUBERKROPP K., A. MICHELIS, H.J. LORCH \& J.C.G. OTTOW. 1988. Effect of sewage treatment plant effluent on the distribution of aquatic hyphomycetes in the River Erms, Schwbische, F.R.A. Aquatic Botany. 32:142-153.

WOOD-EGGENSHWILER S. \& F. BARLOCHER. 1983. Aquatic hyphomycetes in sixteen streams in France, Germany and Switzerland. Transactions of the British Mycological Society. 81:371-379. 